Journal of Applied Finance \& Banking, Vol. 11, No. 1, 2021, 99-120

ISSN: $1792-6580$ (print version), 1792-6599 (online)

https://doi.org/10.47260/jafb/1117

Scientific Press International Limited

\title{
Credit Risk Management and Efficiency of Savings and Credit Cooperative Societies: A Review of Literature
}

\author{
Josiah Aduda ${ }^{1}$ and Stephen Obondy ${ }^{2}$
}

\begin{abstract}
The objective of this paper was to conduct literature review on how credit risk management impacts efficiency and to identify the knowledge gaps in the relationship between the two variables. This study will help the government in policy direction as far as growing the financial sector as a precursor to credit risk management and its contribution to growth in terms of improved savings, improved per capita income, improved credit to private sector and increased employment levels both directly and indirectly. From the empirical studies reviewed, credit risk management was found to influence financial performance but there is no concrete evidence on the relation that credit risk management has with efficiency of SACCOs. The previous studies have mostly focused on financial performance instead of efficiency and they also differ on the direction of the relationship between the two variables. The difference in findings among the scholars might arise from methodological differences and operationalization of the study variables. Contextual differences might also explain the inconsistent findings as most of the studies have focused on commercial banks and in different economies. Future studies should investigate underlying variables that can explain the relationship between credit risk management and efficiency of SACCOs.
\end{abstract}

Keywords: Credit risk management, efficiency, SACCOs.

${ }^{1}$ Department of Finance and Accounting, University of Nairobi.

2 Department of Finance and Accounting, University of Nairobi.

Article Info: Received: October 17, 2020. Revised: November 7, 2020.

Published online: November 20, 2020. 


\section{Introduction}

This chapter presents literature on credit risk management and efficiency of savings and credit cooperative societies.

\subsection{Background of the Study}

Credit risk management is crucial among lending institutions. Savings and Credit Cooperative Societies (SACCOS) must ensure that the risks they are exposed to are mitigated since they affect their objective which is primarily availing savings and credit to owners in the most efficient way possible (Kariuki, 2017). Efficiency of SACCOS is greatly influenced by its credit risk since its gross revenue is generated from issue of loans to customers and earning interest. Therefore, credit risk should be properly managed (Bhattarai, 2016). Non-Performing Loans (NPLs) is a pointer of poor efficiency and has possibility of threatening the commercial bank's overall credit system and lessen its value (Kagoyire \& Shukla, 2016).

This study will be based on several theories such as modern portfolio theory (MPT), Merton's default risk theory, stakeholder theory, financial intermediation theory, the adverse selection theory and the theory of asymmetric information. The MPT by Markowitz (1952) states that the diversification of portfolios is a game changer to many successful SACCOs. To minimize the risks arising from lending to individuals, SACCOs can utilize this element to identify high-risk and low-risk loan applicants. According to the Stakeholder theory, the credit or loan markets are shaped by banks' (lenders) strategies including the screening of potential clients and addressing the opportunistic behavior which is influenced by the nature of loan contracts. In this regard, credit pricing is increased by lenders up to the level in which they expect a maximization of returns. This action helps to exclude the small, risky and expensive borrowers. The adverse selection theory explains the situation in which banks are unable to distinguish safe borrowers from risky ones. The adverse selection theory Stiglitz and Weiss (1981) explains the situation in which banks are unable to distinguish safe borrowers from risky ones. According to the theory, the bank (lender) has insufficient information concerning loan customers. Moral hazard arises because lenders do not have sufficient information to assess and believe the wealth of the borrowers will have accumulated by the due date that the debt should be repaid, as opposed to the time of application.

While initiatives on credit risk management have been increasingly conducted by financial institutions like banks and insurance firms, this is hardly practiced in SACCOs, and the result of this has massively impacted their efficiency (Gauld, 2016). With increased competition credit advancement to low income earners with a high default rate, SACCOs experience increased credit risk level for which if no efforts are put to adopt effective credit risk initiatives to minimize the risk, the efficiency of these institutions will be called into question (Nikolaidou \& Vogiazas, 2014). 


\subsection{Credit Risk Management}

These are the systems, controls and procedures, instituted by companies and expected to ensure efficiency in the collection of payments from customers and thereby reducing the likelihood of non- payment (Kalui \& Kiawa, 2015). A number of the policies used in credit risk Management include decision-making policies expected to aid in the reduction of exposures to credit asset classification loan loss provision (Tanui, Wanyoike \& Ngahu, 2015). This is an area of great concern to many financial organizations. As such, a need to develop well-functioning systems and processes expected to improve future performance visibility is desirable for such financial organizations (Gakure, Ngugi, Ndwiga \& Waithaka, 2012). It involves the identification, measurement, mitigation, monitoring and control of all exposures to credit risk (Raad, 2015).

The primary stage in the process of managing credit risk is the identification of the risk (Ngwa, 2010). The process of the identification of harmful situations and making attempts to characterize them is the process of risk identification. This process involves deliberate attempts to examine, review and predict possible risks (Kimotho \& Gekara, 2016). Risk identification involves analyzing current and future risks to the firm more comprehensively in all the business functions such as asset management operations and others (Ngwa, 2010). In the effective management of credit risks, commercial bank managers are required to know the risks likely to affect the bank. It is important to ensure that they don't miss any risk during this stage and they can achieve this by establishing an appropriate credit risk environment (Mutua, 2015).

The analysis of credit risk involves the examination of the creditworthiness of members-borrowers. This involves examining the repayment sources and the credit history of the members-borrowers (Lagat, Mugo \& Otuya, 2013). Credit appraisal and analysis involves the screening of clients to make sure that they not only have the ability to repay but also be willing to repay the loans on a timely basis (Kurui \& Kalio, 2014). Credit risk analysis creates a deeper understanding of risk and its importance to organizations since it assists them in risk-based analysis and in comparing risks, which is helpful to organizations in prioritizing risk events (Kimoi, Ayuma \& Kirui, 2016). Credit risk analysis is done in identifying and weighing all events preventing repayments of future credit and by implication the borrower's capacity in repayment of the facility (Ngwa, 2010).

Risk control or mitigation involves the use of physical standards, tools, staff training techniques in preventing, reducing or eliminating the expected consequences or threats caused by risks (Ngwa, 2010). The final stage in the process of managing risks is monitoring which involves defining the guidelines that recognize and report possible shortcomings of credit and other transactions to ensure they are closely monitored, corrected and provisioned (Makori, 2015). It involves creating a constant contact with clients. This is meant to depict the bank as being trustworthy and a good problem solver (Mutua, 2015). The most common credit risk management indicators include risk identification, risk analysis and control or 
minimization (Thomas et al., 2017).

\subsection{Firm Efficiency}

Firm efficiency is the ability of a firm to reduce waste while maximizing resource capabilities so as to offer to its customer's quality goods and services (Kalluru \& Bhat, 2009). It involves identifying wasteful resources and procedures affecting productivity and profitability of organizations. Firm efficiency involves designing new work procedures that improves quality and productivity (Darrab \& Khan, 2010). According to Cooper and Rhodes (1978), firm efficiency is the maximum ratio of the weight of outputs to that of inputs.

There are several forms of efficiency. Institutional efficiency defines the relation between achievements of organizational objectives resource utilization. It measures the degree to which an entity's output quantity for selected inputs is different from outputs to inputs of the entiry with the best performance industry wise or cluster under consideration (Kuosmanen \& Johnson, 2017). Technical efficiency is the degree by which a firm produces a quantity of outputs like revenues from specific inputs like various costs. It requires the adoption of a technologically efficient process to maximize outputs from selected inputs (Arunkumar \& Kotreshwar, 2012). Allocative efficiency on the other hand is extent by which firms utilize inputs in several ratios while considering current technology and prices. It refers to the maximization of outputs through the selection of technically efficient input combinations. A combination of technical and allocative efficiency yields economic efficiency, also referred to as productive efficiency (Hackman, 2018).

Various methods are used in the measurement of efficiency. Data envelopment analysis (DEA) and free disposal hull (FDH) are examples of non-parametric frontier approaches to measure efficiency that relies on technical efficiency. When firm or departmental efficiency is benchmarked to top performers in an effort to eliminate underproduction of outputs or input wastage in the firm it is called frontier analysis. This is so because the object is the identification of the entities' location in relation to the most efficient frontier from a pool being considered. Hence, efficiency from the frontier perspective is a relativity concept (Rao \& Lakew, 2012). A number of ratios measure firm efficiency. The first is the total asset turnover ratio which measures how a company is able to generate sales from its total assets. This is measured by the quotient of net sales and average total assets. The second ratio is the fixed-asset turnover ratio which is similar to total asset turnover ratio with the exception that it considers fixed assets only. The fixed-asset turnover is calculated by division of the net sales by average net fixed assets. Another ratio used to measure firm efficiency is revenue turnover which measures the ability of the company to spend considering its investment in generating revenue. It is the ratio of total outputs to total inputs. This ratio show if the firm is managing inputs efficiently which will impact its overall efficiency (Arunkumar \& Kotreshwar, 2012). 


\subsection{Savings and Credit Cooperative Societies}

A SACCO is a financial institution which gives its customers saving and borrowing facilities. They are also called credit unions, which gives credit at low interest rates compared to the banks and other financial institutions. World Council of Credit Unions (WOCCU) is a body that enables sustainable development of credit unions in the world (Aggrey, Eliab \& Joseph, 2010). Individuals who hold accounts in the Savings and Credit Cooperative Societies (SACCOS) are in the meantime the proprietors, and they lead their voting command on the one member - one vote regardless of the individuals' shareholding. This implies that only the customers from these establishments can save and borrow from these SACCOS (Halkos \& Tzeremes, 2012).

Sound risk management has been designed by several SACCOs in order to achieve their financial goal. However, there have been challenges in designing optimal risk management strategies in SACCOs due to constant variation in factors such as economic conditions. According to Pandey (2010) it is necessary for SACCOs to come up with efficient practices to safeguard their credit operations. This is necessary since SACCOs generate their income from credit creation. This means that the repayment of loans given involves a lot of uncertainties. Studies shows that loan application request are decided based on subjective risk parameters relating to the borrower's repayment (Fayman \& He, 2011).

Credit to the members is an important activity of the Sacco's hence the importance of credit risk management. The primary cause of SACCOs failing is because of weak risk management (Mugo, Muathe \& Waithaka, 2019). The returns from investing in business are a compensation for the risk born by the owner of the business. Good credit risk management practice can enable SACCOs to lower their overall exposure to risks of financial nature. These will ensure that, they are able to readily compete in financial sector with other well-established commercial banks (Odhiambo, 2019).

\subsection{Research Problem}

The efficiency of SACCOs is expected to be the result of several factors such as credit risk, size of entity, degree of adoption of technology, managerial competency, and age of the SACCO (Li \& Zou, 2014). Among SACCOs, credit risk is caused by limited institutional capacity, volatile interest rates, inappropriate credit policies, poor management, low capital and liquidity levels, inappropriate laws, direct lending, poor loan underwriting, , massive licensing of banks, moral hazards and an adverse selection due to asymmetry in information. Efficiency of SACCOs is greatly impacted by credit risk because a large portion of revenue is from loans issued on which interest is charged. As such, the management of credit risk is crucial (Bhattarai, 2016). From prior studies, management of this risk predicts the efficiency as far as finance is concerned. For example, non-performing loans which indicate credit risk have the potential to destabilize the credit systems of SACCOs thereby reducing their efficiency (Afriyie \& Akotey, 2012). 
The purpose of establishing SACCOs is to assist the low income earners and small entrepreneurs, to access affordable financing. However, most SACCOs have failed to achieve this objective owing to the many redundant loans (Akide, 2015). In contrast to institutions like commercial banks, SACCOs have no collateral requirements to enable their member's access credit facilities. The only requirement is a guarantee of other SACCO members to obtain credit (Kurui \& Kalio, 2014). The result of this is that SACCOs have been exposed massive like payment default, leaving the SACCOs with the only option of pursuing the guarantor members in an effort to recover the money lent. This directly affects the efficiency of SACCOs which can cause the achievement of their core objectives fearing a re-occurrence of the same.

Empirical evidence is largely focused on the influence of credit risk management on financial performance of financial institutions and mostly commercial banks. The findings have also not been consistent. Adebayo (2017) sought to investigate the relationship between credit risk management and the performance of banks in Nigeria. The findings reveal that there is a significant negative relationship between the asset quality and the financial performance of banks in Nigeria. A study by Sujeewa (2015) assessed how the management of credit risk impacts banks' performance and established that the non-performing loans and its provisions have an adverse effect on commercial banks profitability in Sri Lanka. Alshati (2015) investigated how managing credit risk affects how Jordanian commercial banks perform financially. The conclusions of the study were that indicators of credit risk management were important to promote better performance of the Jordanian banks. Locally, Mamet (2018) sought to determine how credit risk management initiatives impact performance of SACCOS in Uasin-Gishu County. From the findings, it was noted that: credit policy, rates of interest management, financial review and debt recovery has a substantial impact on financial performance of SACCOs. Kimani (2018) sought to investigate the relation between credit risk management and loan performance among DT-SACCOs headquartered in Nairobi County. Results from the study suggest that there was a significant positive correlation between credit risk scoring and loan performance while credit monitoring had no significant influence. Orang'i (2018) conducted a study on the effect that credit risk management has on financial performance of Kenyan banks and established that risk identification has a negative and insignificant effect on financial performance while risk monitoring had a positive but statistically significant effect on financial performance. Nyabicha (2017) did a research on how managing credit risk impacted the performance of commercial banks listed in the NSE in Kenya and concluded that there was a negative significance on the variables used to measure credit risk on the financial performance of Kenyan banks with a listing at the NSE in Kenya.

From the foregoing, although there are previous studies done on the study variables, there exist conceptual, contextual and methodological gaps. Conceptually, most of the previous local and international studies have focused on the relation between credit risk management and performance which is different from efficiency. Further, previous researchers have operationalized credit risk management differently and 
therefore findings are specific to the operationalized method used. Contextually, most of the existing literature focuses on emerging markets with little research on developed and less developed markets. Further, the focus has mostly been on commercial banks whose operations and objectives are different from those of SACCOs. Methodologically, there exist non-uniformity in research methodologies adopted and this can explain the difference in findings. The current study was motivated by these research gaps and attempted to answer the research question; what is the documented effect of credit risk management on efficiency of SACCOs?

\subsection{Research Objectives}

The general objective of this study is to investigate the documented relationship between credit risk management and efficiency of SACCOs

The specific objectives are;

a) To conduct a review of literature on the relationship between credit risk management and efficiency of SACCOs.

b) To identify the knowledge gaps in the relation between credit risk management and efficiency of SACCOs.

\subsection{Value of the Study}

The study's findings will be used for future reference by researchers, students and scholars seeking to study correlated or similar topics. The study will also be beneficial to researchers and scholars to identify other fields of research through the citation of other topics that require additional studies and empirical studies in determining study gaps.

The findings will benefit managers who are tasked with the responsibility of managing SACCOs and other financial institutions since the study will provide useful information and recommendations that will assist them to more informed managerial decisions that will maximize shareholders wealth.

To government and organizations such as the Central banks, in the formulation and implementation of policies and regulations governing monetary policies and credit risk to ensure a stable financial sector so as to stimulate economic growth and lower its spiral effects on the economy. This will contribute to the advancement of monetary development and improvement the economy.

\subsection{Organization of the Paper}

This independent study paper is divided into four chapters. Chapter One introduces the topic by giving the background of the study, introducing the dependent and the independent variable and the relationship between both variables. It also highlights the research objectives and the value of the study. Chapter two reviews the literature of the key underpinning theories in the area of credit risk management and the theoretical framework. Chapter three outlines the empirical studies which have been carried out on the relationship between credit risk management and efficiency and summarizes the general and specific gaps found in the studies. Chapter four gives 
the summary of the empirical studies, conclusion, knowledge gaps identified and recommendations for further research.

\section{Theoretical Literature Review}

\subsection{Introduction}

This Chapter discusses the key theories underpinning credit risk management and efficiency, the chapter further discusses the theoretical framework supporting the study variables and also identifies the research gaps based on the discussed theories and theoretical arguments by previous empirical studies.

\subsection{Theoretical Literature Review}

This study reviews the theories which inform the study. Theories help to clarify and underpin the study concepts and relationships in a clearly defined manner or bring out how the current study can be supported by the theory propositions. The theories reviewed are; the theories that relate to this study are; modern portfolio theory, Merton's default risk theory, financial intermediation theory, stakeholder's theory and information asymmetry theory.

\subsubsection{Modern Portfolio Theory}

The theory was conceived and advanced by Markowitz (1952). The theory asserts that there are four steps in the construction of portfolio as: security valuation, asset allocation, portfolio optimization and the performance management (Seibel, 2012). According to the theory, many companies use models for value at risk to manage market risk and interest rate risk exposures. According to Margrabe (2007), in spite of credit risk remaining the significant risk that faces most SACCOs, the habit of utilizing this theory to credit risk management is yet to be fully embraced. The theory, hence, seeks to bring forth the significance of credit risk management for the SACCOs to remain efficient.

Although each SACCO's mechanisms varies, the common practice approach involves the periodical assessment of credit quality, credit exposures, application of a suitable credit risk rating, and also aggregating the outcome of the assessment to establish a portfolio 's anticipated losses (Waithaka, 2012). Gakure et al. (2012) stated that the basis of the asset-by asset approach is a sound loan appraisal and effective internal credit risk rating systems. Using this approach, a loan appraisal and credit risk rating system allows the management to establish key changes in an individual's credits, or portfolio on time.

Essendi (2013) asserts that the MPT assumes that investors desire to maximize returns from investments for a specified risk level and provides a framework that specifies and measures investment risk and develop relationships between risk and anticipated returns. A key weakness of the asset-by-asset approach is that it has difficulties establishing and evaluating concentration i.e additional portfolio risk emanating from heightened exposure to a mortgagor, or to a group of correlated mortgagors. Modern portfolio theory of management is useful in the study as it 
explains the needs to understand variables affecting the efficiency of SACCOs including credit risk, value at risk, distance to default among others. The theory advocates for usage of portfolio quality ratios and productivity indicators in order to properly and effectively manage credit risk (Kairu, 2009).

\subsubsection{Merton's Default Risk Theory}

Merton's default theory was conceived by Merton (1970). The theory has extensively been utilized in the assessment of defaults in cooperatives and mortgage lending firms. Merton's model postulates that credit analysts are required to appraise financial institutions, while also checking on the firms' liquidity throughout the period of analysis and debt expiry (Jorion, 2014). It has been used to determine the ability of debtors to pay their debt obligations and can thus help credit analysts to determine an organization's credit default risk.

Merton's theory was based on standard assumptions on the firm's capital structure (Merton, 1970). In the case of a default, the firm's assets market value in relation to the liabilities of the company fall below the required limit and thus, the firm is said to have defaulted. A reason for the default in the banks and SACCOs is attributed to credit risk one of the risks experienced by financial institutions (Jorion, 2014).

Credit appraisal is the primary step in the process of customizing a solution to befit the needs of customers. The evaluation begins with a comprehensive understanding of the needs of customers and capability to make sure a good fit is found in terms of financing solutions. Credit appraisal is quite an important safeguard to ensure the underlying quality of loans being advanced and is considered an essential ingredient of credit risk management since the credit analyst is able to establish credit worthiness of a mortgagor and also the value of security offered (Cade, 2009).

This model is critiqued by Jones (1984) who asserts that the default risk for the Merton Model is so low that pricing ability for investment-grade bills is not better than a pure model that assumes no default risk. Afik et al. (2016) in their investigation, found that simplified applications of the Merton model are more superior in comparison to more complex and arithmetic intensive methods and recommended use of a more simpler model.

The theory has purpose to the study as it seeks to evaluate credit risk analysis in financial institutions which is a key variable in the study. The Merton's model asserts that analysts should assess the ability of the firm to remain liquid throughout the period under analysis which delves into the financial stability of the firm. The theory is of great importance to this study as it affirms the importance credit analysts being able to establish the ability of a SACCO member to pay their debts and thus establishing the overall organization's credit risk.

\subsubsection{Financial Intermediation Theory}

The proponent of this theory was Diamond (1984). According to Levine, Loayza and Beck (2000), the theory of financial intermediation has a key function in the banking relationship to overcome information asymmetry between the borrower 
and the lender and thus continues interaction enables the lenders to produce credit worthy information to the borrowers. The availed information provides strong proportion to credit and loan officers to assess and appraise the credit to borrower. Current theories assert that financial intermediaries are built on economic imperfections that emerge in the 1970s with minimal contributions (Jappelli \& Pagano, 2006). Financial intermediaries exist due to their ability to decrease both transactional and informational costs arising from information asymmetry (Tripe, 2003).

Various participants in financial sectors including banks, SACCOs, fund managers, insurance firms and other sector agents typically constitutes valuable varied credit informational details on the determination of the value of assets and securities on offer at the market. Theory of asymmetric information problems often arise to nonfinancial firms issuing a security is bestowed with information on potential flow of cash linked to the security than borrowers. Further some individuals have more details concerning the value of a security than other borrowers. Theories of financial intermediation has a positive contribution to economic growth since it acts as a measure on the rate of saving channeled to investment activities or social -marginal productivity of investment that contributes to financial development and positive economic growth (Klein, 1992).

The major criticism facing the current state of financial intermediation theory is that fails to recognize the role of risk management lenders in the banking relation (Levine et al., 2000). Scholtens and Van Wensveen (2000) are against the view that risk management is only recently important to the financial industry and highlights the concept of participation costs. They suggested ways in which the theory might be further developed to comprehend the current issues in the financial services sector.

This theory aided in addressing efficiency of SACCOS due to the fact that they take numerous risk measures by using advanced credit technology collating and collecting private information, treat, screen and monitor borrowers efficiently (Jappelli \& Pagano, 2006). Financial intermediaries help reduce transaction costs and information costs which are normally caused by information asymmetry. Financial intermediaries therefore help in efficient functioning of the markets.

\subsubsection{Stakeholder's Theory}

The theory by Freeman (1984) was to be used as a managerial tool. It has however since evolved to become a firm theory with a high explanatory potential. The theory is similar to a business ethics and management tool that covers moral and ethical principles in management of a business or other organizations. Stakeholder theory majorly focuses on equilibrium of the interests of the stakeholders as the core corporate policy determinant. The theory has a large contribution to risk management as an addition to implicit contracts theory as well as other forms of contracts, like financing and sales (Cornell \& Shapiro, 1987).

In various industries, like high-tech services, consumer trust is crucial for them and 
being able to maintain offering of such services in future, can significantly improve company value. The value such claims is however highly dependent on probable financial distress costs and/or bankruptcy. This is because management practices on corporate risks can front the lowering of these expected costs, raising the company value (Klimczak, 2005).

Key (1999) argues that the theory may be the optimal model to provide a description of firm behavior replacing the dominant view which is the firm's economic model. However, the present conceptualizations of the theory hardly meet the scientific theory requirements. Therefore investigations into the roots of stakeholder "theory", criticizes its forms, suggesting that measures can be taken for the theory to satisfy its conceptual requirements. To be specific, the studies state that there may be contractual interests underlying stakeholder relations as they do in a normal agency relation between management and shareholders as stated by the conventional economic theory. The theory however provides a diversified insight into feasible rationale for risks management such as bad debt. The theory has however not been tested directly yet. A hypothesis investigating financial distress only provides indirect evidence (Judge, 2006). Stakeholder theory is relevant to the study as it highlights such effects as insider lending and directors' fraudulent and absurd acquisition of loans.

\subsubsection{Information Asymmetry Theory}

Akerlof (1970) established the theory which asserts that both borrowers and lenders experience information asymmetry in their interactions. The phenomenon emanates from a borrower who borrows a loan and has information with regard to the probable risks related to the investment ventures for which the loan is intended. The lender, however, is unaware of the information (Edward \& Turnbull, 2013). The concealed details generate adverse selection and moral hazard problems (Horne, 2012).

Since SACCOs and other lenders are not able to manage and influence financial misappropriation of all credit seekers as a result of inadequate and costly information, Stiglitz (1970) asserts that lenders tend to formulate loan contractual terms to entice borrowers to take actions in favor of the lenders and to induce low risk credit seekers. The resultant effect being equal interest rates at which the demand for loans outperform the credit supply. The amount of the credit advanced and the amount of security, also influence the character of credit seekers and the distribution of the funds advanced, and likewise the return to lenders (Moti et al., 2012). Non-performing loans reduce the capital resources of the affected lenders, leading to their inability to expand their lending business (Taylor, 2013).

Horne (2012) critique information asymmetry for two major reasons: a signal has been argued to have an impact on information asymmetry which is an incorrect assumption and the investors who are influenced by information asymmetry situations are either ambiguously specified or not specified. The information asymmetry theory is however fundamental in understanding the need for disclosure 
in the issuance of loans in the industry. Credit risk in the market arises owing to unknown factors which could influence efficiency of SACCOs. The research will thus seek to evaluate how SACCOs could better appraise such factors so as to reduce losses and increase the efficiency through maintenance of good loans that do not go into delinquency.

\subsection{Theoretical Framework}

This section entails a discussion of the theoretical relationships between the key study variables. It explains the direct relationship between predictor variable, credit risk management, and the response variable, efficiency, as well as the mediating effects of asset quality and moderating effects of SACCO characteristics.

\subsubsection{Credit Risk Management and Firm Efficiency}

The stakeholder theory provides a diversified insight into feasible rationale for risks management such as bad debt. The theory has however not been tested. A hypothesis investigating financial distress only provides indirect evidence. Adverse selection theory states that agency costs have to be incurred by principals to minimize the conflict. Such costs include costs of monitoring costs (incurred by shareholders in following up managers and minimizing agents' divergent activities), connection costs (incurred by managers for optimal contracts that are used as a warranty that no harm will befall the interests of the principals from their actions) and outstanding loss costs (arising from divergent judgments of agents from judgments leading to wealth maximizations of the principals) (Judge, 2006).

Credit risk in the SACCOs arises from moral hazards and an adverse selection resulting from information asymmetry. SACCO efficiency is to a great extent influenced by the credit risk of the bank since SACCOs revenue' huge amount is derived from loans issued on which deriving of interest is done. Nevertheless, Sacco's performance is highly limited by credit risk. As such, it must be properly managed (Bhattarai, 2016). An example, loans that are non-performing which is a credit risk indicator has the potential to destabilize commercial SACCO's general system of credit and reduce the SACCO's efficiency (Afriyie \& Akotey, 2012).

\subsubsection{Credit Risk Management, Asset Quality and Firm Efficiency}

Asymmetric information theory states that specialization is important among workers since they are able to work at their best in the skill that they are good at hence promote productivity. Asymmetric information theory is a good model for explaining a competitive market behavior. Its key concepts are adverse selection, counteracting institutions, signaling and screening. This theory has been used among different examples and market scenarios hence promoting its credibility (Arkelof, 1970).

Asset quality shows a SACCO's asset risk situation and financial strength. Asset quality forecasts the degree of credit risk among the dynamics which affects the health status of a SACCO. The value of assets controlled by a specific SACCO 
relies on the amount of credit risk, and the assets quality controlled through the SACCO also relies on liability to particular risks, tendencies on NPLs, and the costeffectiveness of the debtors to the SACCO (Athanasoglou et al., 2008). Preferably, this ratio ought to be at a minimum. If the lending books are vulnerable to risk in a smoothly operated SACCO, this would be reflected by advanced interest margins. On the other hand, if the ratio decreases it entails that the risk is not being appropriately recompensed by margins (Dang, 2011).

\subsubsection{Credit Risk Management, SACCO Characteristics and Firm Efficiency}

Financial distress theory holds that distress is characterized by a number of factors such as inability to settle debts as they fall due, reduction or inability to pay dividends, current liabilities with a faster maturity rate as compared to current assets. Such activities occur just prior to when payments for outstanding obligations fall due (Whitaker, 1999). Boritz (1991) asserts that the characteristics of financial distress include unfavorable economic conditions combined with poor management of financial risk. The ability of commercial SACCOs to provide cash to investors and conditions that make depositors to rush to withdraw their deposits causing SACCO run should be monitored as this will put the SACCO in liquidity problems hence liquidity risk.

Credit risk is a crucial and a costly risk for any financial institution. It has the most substantial impact in comparison to other risks that face the financial sector because it threatens the solvency of a firm (Sufi \& Qaisar, 2015). Loans that are issued by lenders are subject to this risk but lenders derive the confidence to lend from the understanding that borrowers will meet their repayment obligations without fail thus preventing them from becoming non-performing loans (Bhattarai, 2016). Nonperforming loans significantly lower SACCOs efficiency. This means that the SACCOs may not have sufficient measures to effectively manage credit risk (Afriyie \& Akotey, 2012).

\subsubsection{Credit Risk Management, Asset Quality, SACCO Characteristics and Firm Efficiency}

According to moral hazard theory, during a lending contract, lenders do not have sufficient information to assess and believe the level of wealth accumulated by borrowers by the due date that the debt should be repaid, as opposed to the time of application. When the lenders have no ability to assess the level of wealth of the borrowers, it will be tempting for the latter to default on the borrowing. To reduce this, lenders cover the risk by increasing the rates, which eventually leads to market breakdown (Alary \& Goller, 2001).

Assymetric information theory states that specialization is important among workers since they are able to work at their best in the skill that they are good at hence promote productivity. Asymmetric information theory is a good model for explaining a competitive market behavior. Its key concepts are adverse selection, counteracting institutions, signaling and screening. This theory has been used 
among different examples and market scenarios hence promoting its credibility (Arkelof, 1970).

\section{Empirical Literature Review}

\subsection{Introduction}

The chapter identifies and discusses empirical literature on the basis of how credit risk management and efficiency relate. Literature review requires the logical identification, sorting and analyses of documents with relevance to the stated research problem. The sources of literature include academic journals, books and articles that relate to the study attributes. The chapter also shows the hypothesized relationship between the study variables.

\subsection{Empirical Studies}

This section presents empirical work done on the relation between credit risk management and firm efficiency, the mediating role of asset quality and the moderating role of SACCO characteristics.

\subsubsection{Credit Risk Management and Firm Efficiency}

Mamet (2018) investigated the effects that credit risk management initiatives had on financial performance of SACCOS in Uasin-Gishu registered by the County Enterprise Development Fund (CEDF). A descriptive survey design was appropriate in this study. The study used one official from all 320 registered and active SACCOs together with 9 members of the CEDF board of management. From the population, a sample of 178 respondents was obtained utilizing the Yamane sample size selection formula; census sampling technique and stratified simple random technique were selected as sampling methodologies. A combination of both primary and secondary data was used in the study and was obtained using questionnaires, interviews and data forms. Processing of the data was then done using inferential and descriptive statistics. The results revealed that: credit policy, management of interest rate, financial review and debt recovery had a substantial relation to financial performance of SACCOs.

Kimani (2018) sought to investigate the relationship between credit scoring, credit monitoring and credit risk diversification and loan performance among DTSACCOs headquartered in Nairobi. A descriptive study of credit risk management techniques used by SACCOS was conducted. The study focused on 36 DTSACCOs headquartered in Nairobi y. The study relied on primary and secondary data. Primary data was collected using structured and semi-structured questions and open and close ended questions. These questions were presented to credit managers and credit officers. A regression analysis was done to determine the relationship between the identified techniques and loan performance. Results from the study suggest that there was a significant positive correlation between credit risk scoring and loan performance. The study further established a positive correlation between credit monitoring and loan repayments though the relationship was not significant 
as the case of credit risk scoring. Moreover, this study found that credit scoring significantly influences the ability of borrowers to repay their loans.

Ndalu (2018) focused credit risk management and how it affected performance of DT SACCOs within Kenya. The study adopted a descriptive design; both primary and secondary data were correlated, coded and used. Regression model was developed to show the variables relationship. Quantitative data was tabulated for analysis through descriptive statistics like frequency counts and percentages. The findings showed a positive relation linking the predictor variables (credit risk management practices) and response variable (financial performance) of DT SACCOs in Kenya. The findings and conclusion, the researcher recommends that deposit taking Sacco's should enhance credit management practices such as credit scoring mechanism, standardized and transparent insider lending and credit risk monitoring.

Riasi (2018) sought to determine how credit risk management practice impacts financial performance of deposit taking Sacco's. The design which was used for this study was descriptive design. Research was based on 18 Sacco's in Mombasa County whose performance was analyzed for a period of two years from 2014 to 2015. Information for this study was ancillary data collected from Sacco's and regulator websites. Data was drawn from statements of the Sacco's and was explored using multiple regression analysis, to establish how credit risk management practice impacts financial performance of Sacco's. Data was evaluated using descriptive statistics by Microsoft excel and SPSS. It was noted that, there was a positive correlation among credit risk management practice and financial performance. The four independent variables had positive coefficient indicating that an increase in credit policy, credit appraisal, monitoring and restrictive covenant and credit collateral and agreement result to increase in financial performance.

\subsubsection{Credit Risk Management, Asset Quality and Firm Efficiency}

Irusa (2018) sought to determine how credit risk management policy impacts financial performance of Kenyan banks. Descriptive investigation design was used to gain important data to the study. The study focused on the entire commercial banks that operate in Kenya. Secondary data was derived from the statements of respective banks and the CBK report publications. Descriptive statistics and regression analysis were used data analysis. The study indicated that increased credit risk leads to a reduction in financial performance.

Mogga, Mwambia and Kithinji (2018) sought to analyze how credit risk management procedures used by banks impacted performance in South Sudan. The study was done in Juba city in South Sudan where six banks namely; KCB, Equity, Cooperative, ECO bank, agricultural bank, and Eden commercial banks were targeted. Employees from these banks with different experience levels provided information for the. The researcher used questionnaires in data collection. The computed data was analyzed using descriptive statistics and linear regression. From the study, it was concluded that man of these banks considered risk identification to 
be a process in the management of credit risk management which impacted performance. Risk identification was found to be insignificant to financial performance of the banks; risk analysis and appraisal were both insignificant to financial performance, risk monitoring and credit approval were also substantial to performance.

Orang'i (2018) sought to determine the how credit risk management impacted Kenyan banks' financial performance. The descriptive research was employed for the study. The target population constituted all commercial banks that were in operation between the time frame January 2013 and 31st December, 2017 and analysis of data made using descriptive statistics, correlation and regression analysis as these are conventionally approved tools for descriptive research designs. The findings revealed that risk identification has a negative and insignificant effect on financial performance while risk monitoring had a positive but statistically significant effect on performance. Further, high levels of credit risk were associated with low financial performance.

Adebayo (2017) sought to investigate how credit risk management impacts performance of Nigerian banks. The study targeted twenty one (21) Money Deposit Banks in Nigeria from which: First Bank Nigeria Plc, Eco Bank Plc, GTBank Plc, Access Bank Plc and United Bank for Africa Plc were selected. Reliance was placed on secondary data that was derived from Annual Audited Reports and Prospectus of the banks from 2011 to 2015. Descriptive and Inferential Analyses were conducted on the data using SPSS version 22 and e-Views. From the findings, a substantial negative relation was found between asset quality and performance of the banks.

\subsubsection{Credit Risk Management, SACCO Characteristics and Firm Efficiency}

Gadzo et al. (2019) studied how credit and operational risk impacted the financial performance of Ghanaian universal banks. Data was derived from all the 24 banks, and the findings revealed that credit risk impacts financial performance negatively which was in contrast to empirical studies but in line with the information asymmetry aspect of lemon theory. Operational risk was also found to negatively influence financial performance of the Ghanaian banks. Additionally, It was revealed from the study that bank specific variables such as (asset quality, bank leverage, cost to income ratio and liquidity) had a substantial positive impact on credit risk, operational risk and performance of the banks.

Atsango (2018) did an examination on how firm characteristics affect profitability of deposit taking SACCOs in Kenya. The research adopted a descriptive survey design. The population targeted by the study was 135 DT-SACCOs fully licensed by SASRA prior to the study period with cumulative financial data for the five year study period from 2013 to 2017. Analysis of data was done using Stata in which descriptive and inferential statistics were obtained. It was concluded that firm size, asset quality and operational efficiency had substantial impact on profitability while leverage and capital adequacy failed to show a substantial impact on profitability 
the Sacco's.

Rasika, Hewage and Thennakoon (2016) investigated on whether credit risk affects how commercial banks in Sri Lanka performed financially. The research conducted a research on 2 state banks and four private domestic banks. The research was conducted for the period between 2005 and 2014. The research utilized secondary data from the financial statements of the bank. The data collected was analyzed using panel data analysis method. The findings of the study indicated a negative relationship on non performing ratio and capital adequacy ratio on the financial performance which was given by return on equity.

\subsection{Summary of Empirical Literature Review and Key Gaps}

The studies above present knowledge gaps to be filled. First, the reviewed studies provided mixed conclusions on the direct relationship between credit risk management and financial performance or profitability. This is different from efficiency which is the main goal of a SACCO. Very few studies have been conducted on the relationship between the two study variables in both developed and developing economies and therefore need to conduct studies on how credit risk management impacts efficiency of SACCOs.

Previous studies also reveal conceptual and contextual gaps. Conceptually, the findings of previous studies have been inconsistent ranging from a significant positive relationship to no relationship at all. These differences can be explained by the fact that previous researchers have operationalized credit risk management differently and therefore findings are specific to the operationalized method used. Contextually, most of the existing literature focuses on emerging markets with little research on developed and less developed markets. Further, the focus has mostly been on commercial banks whose operations and objectives are different from those of SACCOs.

Further, most of the studies used different research designs with some basing on empirical literature review to come up with conclusions while others review relevant literature to measure the interrelationships among the study variables. Researchers provided mixed and inconclusive results and also failed to document evidence of the likelihood that further innovation will be necessary to generate a more reliable credit risk management model. The different views from different authors therefore necessitates intervention by future studies to fill the gap by conceptualizing how credit risk management influence efficiency among SACCOs. These gaps have shown that research on credit risk management and efficiency relationship still has several grey areas with no empirical consensus. This study highlights the glaring research gaps in the study area and forms the basis for future advancement on credit risk management and efficiency studies.

\section{Summary, Conclusion And Recommendations}

\subsection{Summary}

This independent study paper critically reviewed how credit risk management 
impacts efficiency of SACCOs. The study has identified the specific objectives to be achieved, the value of the study and the organization of the paper. From the studies and findings analyzed, there is a clear indication that financial scholars have not agreed on the nature of relationship between credit risk management and efficiency. The study highlights some of the conceptual arguments by different researchers in the relationship between credit risk management and efficiency.

In this critical review of literature, six key theories underpinning credit risk management and efficiency have been highlighted. These are; modern portfolio theory, Merton's default risk theory, financial intermediation theory, stakeholder's theory and information asymmetry theory. The study underscores the different theoretical arguments that explain the nature of the relationship between credit risk management and efficiency.

Under empirical review, several relevant studies on the study variables were reviewed to bring out the research gaps and the methodologies used for analysis. From the reviewed studies it was evident that credit risk management affects efficiency. However, the findings were varied with some studies indicating the existence of a significant positive relationship while others concluded that there exists no relationship. However, the studies were all carried out using varied methodologies and data was collected for different time periods which could be the justification for the varied results. Most of the studies also focused on the effect of credit risk management on financial performance which is not the same as efficiency.

\section{Conclusion}

From the review of empirical literature, it can be concluded that most studies have not focused on the impact that credit risk management has on efficiency as they have mostly focused on its influence on financial performance which does not necessary imply efficiency. Further, there are conflicting results as to the effect that credit risk management has on performance. Scholars have argued that this may be explained by the variation of the constructs used in research, the varied methodologies and the contexts of the studies. The interdependence of credit risk management and efficiency is being investigated by several researchers. However, researchers have not yet reached a consensus on the role of credit risk management on efficiency.

Efficiency of SACCOS is greatly influenced by its credit risk since its gross revenue is generated from issue of loans to customers and earning interest. Therefore, credit risk should be properly managed. NPLs are a pointer of poor efficiency and have possibility of threatening the commercial bank's overall credit system and lessen its value. It is through the credit risk management that a bank would identify the financial activities and how they can be coordinated to achieve efficiency. The level at which financial policies are formulated appears to be less challenging as compared to that of how to boost efficiency. This is because efficiency requires different coordination which involves policies and activities geared towards 
enhancing credit risk management. It also requires financial information flow to the investors through the right channels from different decision making units.

\section{Recommendations for Further Research}

This study was based on the literature reviewed concerning credit risk management and efficiency. Based on the literature reviewed, the contradictory findings in the review offer a basis of further research. Since financial performance is not synonymous to firm efficiency and as in many prior studies, the findings are specific to proxies used for study variables, and analysis periods. More research in this area of study can be done to examine different periods with more firm efficiency measures.

Future related studies should also consider moderating, intervening, extraneous and control variables on the relationship between credit risk management and efficiency. Such variables would include asset quality, capital adequacy, liquidity, outreach, ownership structures, firm size, firm age, corporate governance, management efficiency, macroeconomic variables among others.

The studies in future should also consider measuring credit risk management as per financial institution ranging from deposit taking SACCOs to small SACCOs and other financial institutions. It would be interesting to find out if SACCOs with different sizes and ownership structures are affected differently by credit risk management and in turn efficiency.

\section{References}

[1] Adebayo, A. (2017). Relationship between credit risk management and the performance of money deposit banks in Nigeria. IOSR Journal of Economics and Finance, 8(2), 38-48

[2] Afriyie, H. O. and Akotey, J. O. (2012). Credit risk management and profitability of selected rural banks in Ghana. Catholic University College of Ghana

[3] Aggrey, N., Eliab, L., and Joseph, S. (2010). Firm size and technical efficiency in East African manufacturing firms. Current Research Journal of Economic Theory, 2(2), 69-75

[4] Ahmed, F. (2018). Relationship between credit risk management and financial performance of grain milling firms in Mombasa County, Unpublished MBA Research Project, University of Nairobi

[5] Akerlof, G. A. (1970). The market for" lemons": Quality uncertainty and the market mechanism. The Quarterly Journal of Economics, 84(3),488-500.

[6] Akide, W. (2015). Institution development and Provision of rural finance expenses and challenges of rural outreach. IFAD rural finance thematic workshop 9th July, 2015 at Nairobi Serena Hotel.

[7] Arunkumar, R. and Kotreshwar, G. (2012). Risk Management in Commercial Banks: A Case Study of Public and Private Sector Banks. SSRN eLibrary 
[8] Bhattarai, Y. R. (2016). Effect of credit risk on the performance of Nepalese commercial banks. NRB Economic Review, Tribhuvan University

[9] Cooper, W. and Rhodes, E. (1978). Measuring the Efficiency of decision making units, European Journal of Operational Research, 2, 429-444.

[10] Darrab, I. A. and Khan, M. R. R. (2010). Development of analytical relation between maintenance, quality and productivity. Journal of Quality Maintenance, 16(4), 341-353.

[11] Diamond, W. (1984). Financial intermediation and delegated monitoring, Review of Economic Studies, 51(3), 393-414

[12] Essendi, L. K. (2013). The effect of credit risk management on loans portfolio among SACCOs in Kenya. Unpublished MBA Research Project. University of Nairobi

[13] Fayman, A., and He, L. T (2011). Prepayment risk and bank performance. Journal of Risk and Finance, 12(2), 133-145

[14] Freeman, R.E. (1984). Response: Divergent stakeholder theory. Academy of Management Review, 24(2), 233-236

[15] Gadzo, S., Kportorgbi, H., and Gatsi, J. (2019). Credit risk and operational risk on financial performance of universal banks in Ghana: A partial least squared structural equation model (PLS SEM) approach, Cogent Economics \& Finance, 7(1), 1-11

[16] Gakure, R. W., Ngugi, J. K., Ndwiga, P. M. and Waithaka, S. M. (2012). Effect of credit risk management techniques on the performance of unsecured bank loans employed commercial banks in Kenya. International Journal of Business and Social Research, 2(4), 221-236

[17] Gauld, R. (2016). Principal-Agent Theory of Organizations. In Frazmand, A. (eds), Global Encyclopedia of Public Administration, Public Policy and Governance. Springer, Cham.

[18] Hackman, C. (2018). Business performance and strategic new product development activities: An empirical investigation. Journal of Product Innovation Management, 12(2), 214-23.

[19] Halkos, G. E. and Tzeremes, N. G (2012). Productivity efficiency and firm size: An empirical analysis of foreign owned companies. International Business Review, 16(6), 713-731

[20] Irusa, C. (2018). The effect of credit risk management policy on financial performance of commercial banks in Kenya, Unpublished MBA research project, University of Nairobi

[21] Jappelli, T. and Pagano M. (2006). Role and Effects of Credit Information Sharing: In TheEconomics of Consumer Credit, edited by G. Bertola, R. Disney and C. Grant, MIT Press: Cambridge, Massachusetts, 347-371.

[22] Jorion, P. (2014). Value at risk: The new benchmark in controlling market risk. Irwin, Chicago, 1, 997.

[23] Kagoyire, A. and Shukla, J. (2016). Effect of credit management on performance of commercial banks in Rwanda (A Case Study of Equity Bank 
Rwanda Ltd). International Journal of Business and Management Review, 4(4), 1-12

[24] Kairu, P. K (2009). Credit Management, Second Edition, Focus Publishers Limited, Nairobi

[25] Kalui, F. M. and Kiawa, E. (2015). Effects of credit risk management procedures on financial performance among microfinance institutions in Kenya: A Case of MFIs in Nairobi County. International Journal of Humanities Social Sciences and Education, 2(3), 81-103

[26] Kalluru, S. and Bhat, K. (2009).Determinants of Cost Efficiency of Commercial banks in India. ICFAI Journal of Bank Management, 8(2), 32-50

[27] Kariuki,N.W. (2017). Effect of credit risk management practices on financial performance of Deposit Taking Savings and Credit Cooperatives in Kenya. IOSR Journal of Business and Management, 19(04), 63-69

[28] Kimani M. (2018). Relationship between credit risk management techniques and loan performance of SASRA regulated deposit taking SACCOS in Nairobi County, Unpublished MBA Project, University of Nairobi

[29] Kimoi, A., Ayuma, C. and Kirui, K. (2016). Assessment of credit risk management practices on organizational performance: A survey of Savings and Credit Cooperative Societies in Eldoret Town Kenya. International Journal of Scientific \& Engineering Research, 7(5), 416-425

[30] Kimotho, D. N. and Gekara, M. (2016). Effects of credit risk management practices on financial performance of commercial: International Journal of Economics \& Finance, 2 (3), 161-189

[31] Kiyai, E. (2018). Effect of credit risk management on the financial performance of the commercial banks listed at the Nairobi Securities Exchange, Unpublished MBA Project, University of Nairobi

[32] Klein, D. B. (1992). Promise Keeping in the Great Society: A Model of Credit Information Sharing, Economics and Politics 4(2), 117-36.

[33] Kuosmanen, T., and Johnson, A. (2017). Modeling joint production of multiple outputs in StoNED: Directional distance function approach. European Journal of Operational Research, 262(2), 792-801.

[34] Kurui, S. K. and Kalio, A. M. (2014). Influence of credit risk management practices on loan performance of microfinance institutions in Baringo County, Kenya. International Journal of Science and Research, 3(10), 22602267

[35] Lagat, F.K., Mugo, R. and Otuya, R. (2013). Effect of credit risk management practices on lending portfolio among Savings and Credit Cooperatives in Kenya. European Journal of Business and Management, 5(19), 93 - 105

[36] Levine, Loayza and Beck (2000). Financial Intermediation and Growth: Causality and Causes, Journal of monetary economics 46, 31-77

[37] Li, F. and Zou, Y. (2014). The Impact of credit risk management on profitability of commercial banks: A study of Europe. Unpublished Project. Umeå School of Business and Economics 
[38] Makori, J. (2015). Challenges Facing Deposit-Taking Savings and Credit Cooperative Societies: A case of the Gusii Region. Interdisciplinary Journal of Contemporary Research in Business, 4(12), 131-144.

[39] Mamet, P. (2018). Credit risk management initiatives and financial performance of SACCOS under the Uasin Gishu Enterprise Development Fund, Unpublished MBA research project, University of Nairobi

[40] Markowitz, H.M. (1952): Portfolio Selection. New York: John Wiley and Sons.

[41] Merton, R.C. (1963). An Inter-temporal Capital Asset Pricing Model. Econometrica, 41 (5): 867-887

[42] Mogga, J. P., Mwambia, F. and Kithinji, M. M. (2018). Effect of credit risk management on the financial performance of commercial banks in Juba city, South Sudan. International Academic Journal of Economics and Finance, 3(2), 93-116

[43] Mugo, D. M., Muathe, S., and Waithaka, S. T. (2019). Performance analysis of debit card services on deposit-taking SACCOs' financial performance: A Case of Kenya. Journal of International Business, 11(2), 23-44.

[44] Mutua, J. M. (2015). Effect of mitigating credit risk on performance of commercial banks in Kenya: A Case of Chuka Town. European Journal of Business and Social Sciences, 4(7), $113-125$

[45] Ndalu, C. (2018). Effect of credit risk management on financial performance of deposit taking saving and credit co-operatives societies in kenya, Unpublished MBA Project, University of Nairobi

[46] Odhiambo, S. P. O. (2019). Determinants of financial performance of savings and credit cooperative societies in Nakuru town, Kenya. Reviewed Journal of International Business Management, 1(1), 42-53.

[47] Orang'i, A. (2018). The effect of credit risk management on the financial performance of commercial banks in Kenya, Unpublished MBA Project, University of Nairobi

[48] Raad, M. L. (2015). Credit risk management practices in commercial banks of Bangladesh: A Study on Basic Bank Ltd. International Journal of Economics, Finance and Management Sciences. 3(2), 78-90.

[49] Rasika, E., Hewage, P., and Thennakoon, K, (2016). Does credit risk affect financial performance of Sri lankan commercial banks. Journal of Financial Management, 2(2), 124-133

[50] Stiglitz, J.E. and Weiss, A. (1981) Credit rationing in markets with imperfect information: American Economic Review, 12(1), 21-33

[51] Sufi, F. A. and Qaisar, A. M. (2015). Credit Risk Management and Loan Performance: Empirical Investigation of Micro Finance Banks of Pakistan. International Journal of Economics and Financial Issues, 5(2), 574-579.

[52] Tanui, J. K., Wanyoike, D. M. and Ngahu, S. (2015). Assessment of Credit Risk Management Practices on Financial Performance among Deposit Taking SACCOs in Nakuru East Sub County, Kenya. International Journal in Management and Social Science, 3(5), 602-610 